\title{
Implementing ESG Concept in Sharia Stock Screening Process
}

\author{
Rifka Mustafidaa,*, Najim Nur Fauziah $^{\mathrm{a}}$ \\ ${ }^{a}$ International Islamic University Malaysia, Malaysia
}

\begin{abstract}
Islam places great importance on the moral, environmental and social dimensions. Sustainable development is centric on the overlapping factors of both Islamic finance and Socially Responsible Investment, which are the economy, the environment, and social impact. On contrary, Empirical evidence concerning ESG practice of IFIs and Sharia-compliant companies are still lacking. The investment portfolio should therefore be scrutinized on the criteria of justice, social welfare, and sustainability. This paper aims to identify the sustainability report of Sharia Stocks companies and propose an i-ESG index for sharia stocks screening in Indonesia. A qualitative study is used to describe sustainability action doing by Sharia-compliant companies listed on Indeks Saham Syariah Indonesia (ISSI) in October 2019. This study found that almost all the companies show their Good Corporate Governance, but only a few of company have their sustainability report. Therefore a novel parameter to screen the sharia stocks screening process is urgently needed.
\end{abstract}

Keywords: ESG, stock screening, sustainable development

\section{INTRODUCTION}

The Islamic finance industry aims to promote firms that are included in sectors or industries that add value to the real economy (Lusyana and Sherif, 2017) Furthermore, investors are concerned with adhering to the Islamic way, but they expect to gain wealth from their investment and in order for investors to invest in Islamic instruments they need to follow Islamic investment principles in line with shariah principles For example, Investments in financial instruments with fixed incomes, such as preferred stocks, bonds, and some derivatives (eg options) are unacceptable, as they promise a fixed rate of return and grant no voting rights (Walkshausl and Lobe, 2012). Furthermore, Islamic investors are not permitted to purchase the stocks of companies whose main business activities are alcohol, gambling, conventional financial services, entertainment, porkrelated products, tobacco, and weapons (Islamic Finance Investment, 2014) Furthermore, certain financial ratios have been used to screen companies For example, Hussein and Omran (2005) reported that when the levels of debt in companies are over one-third of market capitalization, they are not Shariahcompliant stocks.

\footnotetext{
*Author in correspondence,

Email address: rifkamustafida@rocketmail.com (Rifka Mustafida)
}

As the country with the fourth-largest population in the world, with around 275 million people; Indonesia is rich in both renewable and non-renewable sources Moreover, Indonesia, as one of the world's largest Muslim countries, is still behind Malaysia, when based on Islamic finance fundamentals (Darus et al., 2013). Despite the growing need for the Shariah interest trend, together with the growing number of investment needs and the potential as the world's largest Muslim population, the opportunity to develop the Shariah investment is becoming higher.

Islam places great importance on the moral, environmental and social dimension, whereas there are several Quranic verses to define and compliment the environment and encourage people to look after it Narayanan (2013) state that religion plays a role in achieving economic sustainability. The three ways in which religion may play a role in sustainable development are through the values it offers, through its potential for ecological, social, and political activism (based on those values) and through its capacity to enable self-development. The idea was supported by Becchetti and Borzaga (2010), who stated that religion can increase economic growth and environment and economic sustainability.

Abdulrachman (2011) suggested a model of sustainable development consisting of five indicators of sustainable development, namely: (1) socio-cultural development, (2) economic development, (3) political development, (4) environment protection, and (5) spiritual development The model is shown below:

The environment underpinning sustainable development, pe- 
ace, and security is now in danger. Environmental crime is vastly expanding and increasingly endangering not only wildlife populations but entire ecosystems. Environmental crimes can be broadly defined as illegal acts which directly harm the environment. They include illegal trade in wildlife; smuggling of ozone-depleting substances (ODS); illicit trade in hazardous waste; illegal, unregulated, and unreported fishing; and illegal logging and the associated trade in stolen timber, while the illegal logging itself may occur far from the public gaze in remote forest regions, it is driven by demand for cheap timber in consumer markets in affluent nations (Banks et al., 2008).

On contrary, empirical evidence concerning the environmental practice of IFIs and Sharia-compliant companies are still lacking (Darus et al., 2013). The investment portfolio should therefore be scrutinized on the criteria of justice, social welfare, and sustainability The desire for socially responsible behavior category including protection of the natural environment is urgent (Ullah et al., 2014). Islamic Financial institutions (IFIs) and shariah-compliant companies are not allowed to achieve their economic objectives by inflicting harm on the environment and society (Dusuki and Abdullah, 2007). Based on an exploratory study, this paper is going to serve as a blueprint to the policymaker and Islamic capital market on the Islamic Socially Responsible Investment Index in the stock screening process.

This research was conducted to answer the following questions,

1. Do Sharia Stocks companies issue the sustainability report?

2. What are the social environmental crimes of sharia stocks companies?

3. What is the best model to screen the sharia stocks companies?

\section{LITERATURE REVIEW}

Works of literature are writing about Sharia stock screening and sustainable responsible investment as a concept and empirical studies. However, in the Sharia stock discussion, there's still a lack of impactful literature that can give enlightenment on Sharia stock screening from an environmental aspect.

Asutay and Harningtyas (2015) showed the industry mainly focuses on financing the financial sectors as shown in the lowest performance of self or investment in real sectors. It should be noted that there is more exposure to comply with GCG principles while no attention is given to environmental consequences.

An empirical study by Erragraguy and Revelli (2015) also showed that higher performance for Islamic portfolios which integrated positive environmental protection, social welfare, and good governance practices (ESG) screening, particularly in the post-subprime crisis period The next phase of development of Islamic equities should the incorporation of environmental, social, and governance aspects into Shariah stock screening norms.

Moi et al. (2016) explain the concept of sustainable development can be seen by referring to statistical measures step that should be noted and action today to ensure that environmental issues are global in nature such as water pollution, the exchange of weather and the greenhouse effect endured this day would never affect and threaten the life in the future. Sustainable development must take into account social justice, basic human needs, public health, environmental awareness in space and time.

Rahman (2016) discusses ethical considerations that may include, among others, religious affiliations, beliefs, or values. It might be a screening process or variable in the selection process Screens can be either negative (exclusionary) or positive (inclusionary). Negative screening excludes companies that are incompatible with investors' ethical values, while positive screening seeks out companies that act in a manner consistent with the investor's ethical values. Examples of negative screening include excluding companies that are engaged in gambling, pornography, alcohol, tobacco, weapons, and damaging the environment Otherwise, an example of positive screening includes investing in companies that promote environmental improvement, pollution control, community engagement, and sustainability.

Azmi et al. (2017) explain perspective Islamic concept is not easily applied in conventional setting; this indicates the need for more Muslim scholars to become involved in conventional business practices, so that information related to the required category can be discerned to them when screening is conducted the challenging aspect in the stock screening process is identifying the operations that constitute the main activity of a company. The study suggests creating a transparent regulatory environment by establishing a globally acceptable, universal Shariah standard for screening.

Ismail and Shaikh (2017) explain there is much potential for Islamic economy and finance to promote sustainable economic development through such approaches as widening access to finance, financing green infrastructure projects, and preservation of the environment. Sustainable development goals (SDGs) revolve around a human, social well-being, and environmental sustainability. Maqashid Sharia emphasizes human well-being from spiritual, physiological, intellectual, and economic perspectives. Islamic worldview and values framework strengthens moral consciousness, urges pro-social behavior, and engender environmental ethics which can help in influencing our attitudes towards meeting sustainable development challenges.

Zandi et al. (2017) discuss the most Islamic stock screening methodology is to have three stages of screening. For the first stages of screening, industry screening is a must-not have a controversial issue. The second stage is screening on the income statement, this is also important to ensure that the company has halal activities. The last stage is to screen the balance sheet. In this case, two controversial items such as debt and liquidity should be including as part of the screening The ratio should generally agree to be less than $33 \%$.

Shofawati (2018) stated that the mechanism of stock screening according to the fatwa DSN-MUI, the Kuala Lumpur Stock Exchange Islamic Index and the Dow Jones Islamic index are based on two criteria, types of business activity or core activity screening and financial screening, but there is no standard of specification and parameter especially in the financial screening 
criteria of the indices.

Research by Masih et al. (2018) found that Shariah stock screening norms characteristically do not explicitly address elements of environmental protection and conservations, as adopted by SRI funds. Thus in recent times, many stakeholders of Islamic finance have advocated the augmentation of Shariah stock screening criteria to incorporate this aspect.

In Hanif (2019) highlights the issues in the screening process of Shariah-compliant stock universe from Shariah and professional perspectives. The research finds a weakness in the process including variation in tolerance limit (for haram elements), variations in the use of calculation methods (total assets and market capitalization), insufficient income purification mechanism, and confusions about the application of bay' al sarf and bay al dayn regulations. The study argued that certain important areas, like questionable marketing and sales practices and environmental damages, are ignored infiltration.

\section{METHOD}

The qualitative research method is used to interpret a phenomenon, it takes the position that interpretative understanding is only possible by way of uncovering or deconstructing the meanings of a phenomenon (Thorne, 2000). Qualitative data analysis is the classification and interpretation of linguistic (or visual) material to make statements about implicit and explicit dimensions and structures of meaning-making in the material and what is presents in it. Qualitative data analysis also is applied to discover and describe issues in the field of structures and processes in routines and practices (Flick, 2013).

Qualitative data analysis (Thorne, 2000) is used in this study to describe sustainability action doing by Sharia-compliant companies listed on Indeks Saham Syariah Indonesia in October 2019. This analysis also aims to construct the Shariah ESG model in the Sharia stock screening process. Given the objective of this study, Sharia and ESG theories are also adopted to provide an explanation or theory which is relevant in making the model.

\section{FINDING AND ANALYSIS}

Islam is a comprehensive way of life for Muslims, providing rules and guiding principles for all aspects of life. It includes both spiritual or religious aspects and activities governing worldly affairs such as commercial transactions (Marzban and Asutay, 2012). In Islamic finance, an investment should be in line with Sharia. This would require eliminating the elements that are considered unlawful in light of the Shariah from the asset universe when considering Islamic portfolio optimization (Rizaldy and Ahmed, 2019). Sustainable development is centric on the overlapping factors of both Islamic finance and Socially Responsible Investment, which are the economy, the environment, and social impact.

The Quran sends out a clear message to take good care of the environment and protect it, as humankind is not its owner. Therefore, the right to use natural resources implies humankind's commitment to preserving them in a sustainable manner that will ensure the next generations will also enjoy their benefits. All of which will have to be done in a moderate and considerate way (Manoiu et al., 2016). Islam adopted the principle of natural reserves with specified borders and limits. In surah Al Baqarah verse 11, Allah prohibited all mankind to damage the earth. Other than that, the Quran also has extensively mentioned destructions and environmental pollutions that are associated with human actions, one of the verses is from Surah al-Rum verse 41 . Thus, Islam enacted adequate legislation to protect the environment.

Islamic finance and the SRI movement share obvious similarities in their objectives and claims (promotion of social welfare through an emphasis on ethics) (Awad, 2002). A survey conducted among Islamic practitioners revealed that $98.8 \%$ of respondents believed that promoting social responsibility in financial transactions would create value for the Islamic financial industry (Sarially, 2005). In this section, sharia and ESG concepts in stock screening are integrated to be the model of an i-ESG index. Several criteria and elements from Shariah and ESG concept proposed for the model are referred to as Sharia stock screening methodologies from DSN-MUI and ESG screening methodologies from MSCI.

According to this depicted Table 3, the authors' analysis shows that almost all the listed companies are fulfilling the government indicators. The companies disclose more information on good corporate governance. Meanwhile, for the social aspect, not all the company could provide their corporate social responsibility but to some extent, Moravcikova et al. (2015) mentioned that CSR reporting is a major tool of CSR communication, and it is a trend that reveals the company policy related to the environment, sustainability and social responsibility. This CSR report should not only in charge of the company itself but also for the stakeholders to help in the decisionmaking process.

On the other hand, From the report, there are only 9 companies that specifically have their sustainability reports. While others are combining their sustainability details with their annual reports. According to the authors, they are expected to write the sustainability report and publish it to society as large to prove their good business activity. This view is supported by a study by Ching et al. (2014) a good sustainability report is related to the good content of the tree environment, regardless of the economic sector. The company also should disclose its information in an integrated way, addressing sustainability issues under the scope of business strategy.

Similarly, according to Otoritas Jasa Keuangan (2016), a sustainability report is a form of a report undertaken by a financial service institution, issuers, and public companies to disclose or communicate to all stakeholders and society regarding the performance of good environmental, social, and governance in conducting sustainable business. Based on OJK data, currently, the sustainability report in Indonesia is voluntarily managed. However, it has been reached almost $9 \%$ of the total companies listed in BEI which was published their sustainability reports. Its publication is largely almost based on the disclosure standard of the Global Reporting Index (GRI). Up to the end of 
Table 1: i-ESG Parameter

\begin{tabular}{lll}
\hline Categories & Criteria & Element
\end{tabular}

\begin{tabular}{|c|c|c|}
\hline \multirow{15}{*}{ Sharia } & \multirow{10}{*}{ Business Activity } & Financial services based on riba \\
\hline & & Gambling and gaming \\
\hline & & Manufacture or sale of non-halal products or related products \\
\hline & & Conventional insurances \\
\hline & & Non-permissible entertainment activities according to Shariah \\
\hline & & $\begin{array}{l}\text { Manufacture or sale of tobacco-based products or related prod- } \\
\text { ucts }\end{array}$ \\
\hline & & Produce, distribute, trade and / or \\
\hline & & $\begin{array}{l}\text { provide: - haram goods and services, - goods or services that are } \\
\text { morally and / or damaging in nature mudarat; }\end{array}$ \\
\hline & & $\begin{array}{l}\text { Conduct transactions containing } \\
\text { elements of bribery (risywah); } \\
\text { and }\end{array}$ \\
\hline & & Other activities deemed non- permissible according to Shariah \\
\hline & \multirow{5}{*}{ Financial Ratio } & Total interest-based debt compared to total assets \\
\hline & & no more than $45 \%$ (forty-five percent); or \\
\hline & & Total interest income and other non-halal income \\
\hline & & compared to total business revenue (revenue) and \\
\hline & & other income not more than $10 \%$ (ten percent); \\
\hline \multirow{9}{*}{ Environment } & \multirow{3}{*}{ Climate Change } & Carbon Emissions \\
\hline & & Product Carbon Footprint \\
\hline & & Financing Environmental Impact \\
\hline & \multirow{3}{*}{ Natural Resources } & Water Stress \\
\hline & & Biodiversity and Land Use \\
\hline & & Raw Material Sourcing \\
\hline & \multirow{3}{*}{ Pollution \& Waste } & Toxic Emission \& Waste \\
\hline & & Packaging Material \& Waste \\
\hline & & Electronic Waste \\
\hline \multirow{10}{*}{ Social } & \multirow{3}{*}{ Human Capital } & Labor Management \\
\hline & & Human Capital Development \\
\hline & & Health \& Safety \\
\hline & \multirow{6}{*}{ Product Liability } & Product Safety and Quality \\
\hline & & Chemical Safety \\
\hline & & Financial Product Safety \\
\hline & & Privacy and Data Security \\
\hline & & Responsible Investment \\
\hline & & Health and Demography Risk \\
\hline & CSR & CSR Program \\
\hline
\end{tabular}


Table 2: continued

\begin{tabular}{|c|c|c|}
\hline \multirow{8}{*}{ Governance } & \multirow{4}{*}{ Corporate Governance } & $\begin{array}{l}\text { Table 2: continued } \\
\text { Board Diversity }\end{array}$ \\
\hline & & Executive Pay \\
\hline & & Ownership and Control \\
\hline & & Accounting \\
\hline & \multirow{4}{*}{ Corporate Behaviour } & Business Ethics \\
\hline & & Anti-Competitive Practices \\
\hline & & Tax Transparency \\
\hline & & Corruption and Instability \\
\hline
\end{tabular}

Source: Author, 2019

the year 2016, it might be seen that as many as 49 IDX listing companies have published sustainability reports. Therefore, it seems to the authors that the company should have their fairly high enthusiasm in this situation. Mainly because a sustainability report is an important report to be published especially in terms of knowing how the company integrates environmental aspects, Social, and good governance.

\section{CONCLUSION AND RECOMMENDATION}

To conclude, over 30 sharia stocks companies listed in ISSI, almost all the companies are fulfilling the government indicator and disclose more information on good corporate governance. However, in terms of the Social aspect, not all the companies could provide their corporate social responsibility report while CSR report might be a major tool of CSR communication and a trend to reveal the company policy related to the environment, sustainability, and social responsibility. Similarly, there are only 9 companies that specifically have their sustainability reports, while the rest are combining their sustainability details with their annual reports.

Therefore i-ESG index for current sharia stocks screening in Indonesia is needed. This i-ESG parameter included four categories; Shariah, Environment, Social, and Government. Each of the categories is having its own criteria aspects and elements. Moreover, on the way forward, the authors recommend for the regulator to issue an i-ESG model to screen the sharia stocks and the company should aware of the i-ESG concept and implement it in their business activities.

\section{References}

Abdulrachman, S. M., 2011. Integrating spiritual dimension in sustainable development strategy an Islamic perspective. OIDA International Journal of Sustainable Development 2 (11), 51-64.

Asutay, M., Harningtyas, A. F., 2015. Developing Maqasid al- Shari'ah Index to Evaluate Social Performance of Islamic Banks : A Conceptual and Empirical Attempt. International Journal of Islamic Economics and Finance Studies 1 (1), 5-64.

Awad, E. M., 2002. Electronic Commerce: From Vision To Fulfillment. Prentice Hall, New Jersey.

Azmi, A., Non, N., Aziz, N. A., 2017. Challenges to Shariah equity screening , from Shariah scholars perspective. International Journal of Islamic and
Middle Eastern Finance and Management 10 (2), 229-242.

URL: https : //doi .org/10.1108/IMEFM-11-2016-0165

Banks, D., Davies, C., Gosling, J., Newman, J., Rice, M., Wadley, J., Walravens, F., 2008. Environmental Crime. A threat to our future. Environmental Investigation Agency 20.

URL: https://doi.org/10.4135/9781412963930.n180

Becchetti, L., Borzaga, C., 2010. The economics of social responsibility. Rouledge, New York.

Ching, H. Y., Gerab, F., Toste, T. H., 2014. Analysis of Sustainability Reports and Quality of Information Disclosed of Top Brazilian Companies. International Business Research 6 (10), 62.

URL: https://doi.org/10.5539/ibr.v6n10p62

Darus, F., Yusoff, H., Mohd Azhari, N. K., 2013. Environmental Disclosure of Islamic Financial Institutions (IFIs): Preliminary Evidence from Malaysia. Journal of Energy Technologies and Policy 3 (11), 433-439.

Dusuki, A. W., Abdullah, N. I., 2007. Maqasid al-Shari 'ah, Maslahah, and Corporate Social Responsibility. The American Journal of Islamic Social Sciences 24 (1), 25-45.

Erragraguy, E., Revelli, C., 2015. Should Islamic investors consider SRI criteria in their investment strategies? Finance Research Letters 14, 11-19. URL: https://doi.org/10.1016/j.frl.2015.07.003

Flick, U., 2013. The SAGE Handbook of Qualitative Data Analysis. SAGE Publications, California. URL: https://doi .org/10.4135/9781446282243.n1

Hanif, M., 2019. Shariah screening process of capital markets: An evaluation of methodologies. Journal of King Abdulaziz University, Islamic Economics 32 (1), 23-42.

URL: https://doi.org/10.4197/Islec.32-1.2

Hussein, K., Omran, M., 2005. Ethical Investment Revisited: Evidence from Dow Jones. The Journal of Investing 14 (3), 105-106.

Ismail, A. G., Shaikh, S. A., 2017. Role of Islamic Economics and Finance in Sustainable Development Goals. Working paper, IESTAC.

URL: https://doi.org/10.13140/RG.2.2.14806.09288 DOI: $10.13140 /$ RG.2.2.14806.09288

Lusyana, D., Sherif, M., 2017. Shariah-compliant investments and stock returns: evidence from the Indonesian stock market. Journal of Islamic Accounting and Business Research 8 (2), 143-160. URL: https : //doi.org/10.1108/JIABR-10-2015-0052

Manoiu, V.-M., Düzgüneş, E., Azzeddine, M., Manoiu, V.-S., 2016. a Qualitative Exploration of the Holy Quran'S Environmental Teachings. IJAEDUInternational E-Journal of Advances in Education 2 (5), 209. DOI: $10.18768 /$ ijaedu. 43510

Marzban, S., Asutay, M., 11 2012. Standing out with the crowd. The Banker.

Masih, M., Kamil, N. K. M., Bacha, O. I., Masih, M., Kamil, N. K. M., Bacha, O. I., 2018. Issues in Islamic Equities : A Literature Survey. Emerging Markets Finance and Trade 54 (1), 1-26. URL: https ://doi .org/10.1080/1540496X . 2016.1234370

Moi, M. R., Shafiai, M. H. M., Possumah, B. T., 2016. Concept of Sustainable Development from Islamic Perspective. En: the 3rd International Conference on Management \& Muamalah.

Moravcikova, K., Stefanikova, , Rypakova, M., dec 2015. CSR Reporting as an Important Tool of CSR Communication. Procedia Economics and Finance 
Table 3: ISSI Sharia Stocks Listed Companies

\begin{tabular}{|c|c|c|c|c|c|c|}
\hline No & Code of Companies Listed & $\begin{array}{c}\text { Environment } \\
\text { Sustainability Report }\end{array}$ & Annual Report & Website & $\begin{array}{l}\text { Social } \\
\text { Y/N }\end{array}$ & $\begin{array}{c}\text { Governance } \\
\text { Annual Report }\end{array}$ \\
\hline 1 & AALI & $\checkmark$ & $\checkmark$ & $\checkmark$ & $\checkmark$ & $\checkmark$ \\
\hline 2 & ABBA & $\checkmark$ & $\checkmark$ & $\checkmark$ & $\checkmark$ & $\checkmark$ \\
\hline 3 & ACES & $\checkmark$ & $\checkmark$ & $\checkmark$ & $\checkmark$ & $\checkmark$ \\
\hline 4 & ACST & $\checkmark$ & $\checkmark$ & $\checkmark$ & $\checkmark$ & $\checkmark$ \\
\hline 5 & ADES & - & $\checkmark$ & - & $\checkmark$ & $\checkmark$ \\
\hline 6 & ADHI & $\checkmark$ & - & - & $\checkmark$ & $\checkmark$ \\
\hline 7 & ADMG & - & $\checkmark$ & - & $\checkmark$ & $\checkmark$ \\
\hline 8 & ADRO & $\checkmark$ & - & - & $\checkmark$ & $\checkmark$ \\
\hline 9 & AGII & - & $\checkmark$ & - & $\checkmark$ & $\checkmark$ \\
\hline 10 & AKKU & $\checkmark$ & - & - & $\checkmark$ & $\checkmark$ \\
\hline 11 & AKPI & - & $\checkmark$ & - & $\checkmark$ & $\checkmark$ \\
\hline 12 & AKRI & $\checkmark$ & - & - & $\checkmark$ & $\checkmark$ \\
\hline 13 & AKSI & - & - & - & $\checkmark$ & $\checkmark$ \\
\hline 14 & ALDO & - & - & $\checkmark$ & $\checkmark$ & $\checkmark$ \\
\hline 15 & ALKA & $\checkmark$ & - & - & $\checkmark$ & $\checkmark$ \\
\hline 16 & AMFG & - & - & $\checkmark$ & - & - \\
\hline 17 & AMIN & - & $\checkmark$ & - & $\checkmark$ & $\checkmark$ \\
\hline 18 & ANJT & $\checkmark$ & - & - & $\checkmark$ & $\checkmark$ \\
\hline 19 & ANTM & $\checkmark$ & - & - & $\checkmark$ & $\checkmark$ \\
\hline 20 & APII & - & - & - & - & - \\
\hline 21 & APLI & - & $\checkmark$ & - & $\checkmark$ & $\checkmark$ \\
\hline 22 & APLN & - & $\checkmark$ & - & $\checkmark$ & $\checkmark$ \\
\hline 23 & ARII & $\checkmark$ & - & - & $\checkmark$ & $\checkmark$ \\
\hline 24 & ARMY & - & - & - & - & - \\
\hline 25 & ARNA & - & $\checkmark$ & - & $\checkmark$ & $\checkmark$ \\
\hline 26 & ARTA & - & - & - & $\checkmark$ & $\checkmark$ \\
\hline 27 & ARTI & - & $\checkmark$ & - & $\checkmark$ & $\checkmark$ \\
\hline 28 & ASGR & - & $\checkmark$ & - & $\checkmark$ & $\checkmark$ \\
\hline 29 & ASII & $\checkmark$ & - & - & - & - \\
\hline 30 & ASRI & - & $\checkmark$ & - & $\checkmark$ & $\checkmark$ \\
\hline
\end{tabular}

Source: Author, 2019 
$26,332-338$.

URL: https : //doi .org/10.1016/s2212-5671(15)00861-8

Narayanan, Y., 2013. Religion and Sustainable Development: Analysing the Connections. Sustainable Development 21 (2).

URL: https : //doi.org/10.1002/sd.1557

DOI: $10.1002 / \mathrm{sd} .1557$

Otoritas Jasa Keuangan, 2016. Peraturan Otoritas Jasa Keuangan Nomor 55 /POJK.03/2016 Tentang Penerapan Tata Kelola Bagi Bank Umum.

URL: https://www.ojk.go.id/id/kanal/ perbankan/regulasi/peraturan-ojk/Pages/

POJK-tentang-Penerapan-Tata-Kelola-bagi-Bank-Umum . aspx

Rahman, S., 2016. Ethical Investment in Stock Screening and Zakat on Stocks. Journal of Islamic Finance 4 (1), 39-62.

URL: https ://doi .org/10.12816/0024800

Rizaldy, M. R., Ahmed, H., 03 2019. Islamic legal methodologies and shariah screening standards: Application in the indonesian stock market. Thunderbird International Business Review 61.

DOI: $10.1002 /$ tie. 22042

Sarially, S., 2005. Evaluating the 'Social Responsibility' of Islamic Finance: Learning from the Experiences of Socially Responsible Investment Funds. En: Proceedings of the International Conference in Islamic Economics and
Finance, Islamic Economics and Banking in the 21st Century. pp. 433-472. Shofawati, A., 2018. Islamic Screening Mechanism of Islamic Capital Market - A Comparison Between the Fatwa - DSN-MUI , the Kuala Lumpur Stock Exchange Islamic Index and the Dow Jones Islamic Market Index. In International Conference of Organization Innovation (Vol., 1141-1151.

URL: https : //doi .org/10.18502/kss . v3i10.3456

Thorne, S., 2000. Data analysis in qualitative research. Evidence-Based Nursing 3 (3), 68-70.

URL: https : //doi.org/10.1136/ebn.3.3.68

Ullah, S., Jamali, D., Harwood, I. A., 2014. Socially Responsible Investment : Insights from Shari'a Departments in Islamic Financial Institutions. Business Ethics : A European Review 23 (2), 218-233.

URL: https : //doi .org/10.1111/beer. 12045

Walkshausl, C., Lobe, S., 2012. Islamic Investing. Review of Financial Economics 21, 53-62.

Zandi, G., Razak, D. A., Hussin, N. H., 2017. Stock Market Screening : An Analogical Study on Conventional and Shariah-Compliant Stock Markets. Asian Social Science 10 (22), 270-279.

URL: https : //doi .org/10.5539/ass.v10n22p270 